\title{
Comparing Film Language Amongst Genres of Holocaust Films: A Comparative Analysis of Schindler's List, In Darkness and The Last Days
}

\author{
Kathleen H. Cross
}

This paper will provide a comparative analysis of various aspects of genre conventions, film language and other tools used by Holocaust films by analysing three Holocaust films of different genres: Schindler's List, In Darkness and The Last Days. To begin, a brief overview of the history of Holocaust films and the principles that guide them will be provided. Following this will be a short synopsis of each of the three films, as well as a brief analysis of the filmmakers' personal links to Holocaust victims. As the films are all from different genres, a description of the unique genres and subgenres present in these films will be provided. The body of this paper will compare the film language tactics used amongst the three films including: symbolism, camera movement, development of proximate realities and the perception that the films create of Germans, Jews and the Holocaust itself. Using Schindler's List, In Darkness and The Last Days as subjects, this paper will present some of the similarities and differences in film language used amongst Holocaust films of disparate genres.

Following the occurrence of the Holocaust during World War II, a large number of films have been produced depicting the horrific events that took place during this period. Although there were anti-Nazi films released much earlier, Holocaust films did not become widespread until after 1961, following the trial of key Nazi bureaucrat, Adolf Eichmann. Eichmann's highly publicized trial delivered shocking news to the world about the harsh realities of the Holocaust. After his trial, Russia opened their archives from the war, and evidence of the Holocaust became public. ${ }^{1}$ Following the flood of new information about the Holocaust, a large number of films, varying from documentaries to art-house films and even to Hollywood blockbusters, have been released on the subject. Each film and genre of film offers its own unique insight into the horrors that took place for the Jewish population during World War II. Although Holocaust films have always faced controversy, modern films on the subject face a new and interesting time, as the generation who personally experienced the Holocaust is quickly diminishing. This is inevitably leading to a shift in the broad understanding of the Holocaust away from personal recollections and toward collective and artificial memories. ${ }^{2}$ With this transition rapidly occurring, it is likely that Holocaust films will become more impactful to the way the Holocaust is understood in the future.

\footnotetext{
${ }^{1}$ Trudy Gold, "An overview of Hollywood cinema's treatment of the Holocaust," in Holocaust and the Moving Image: Representations in Film and Television since 1933, eds. Toby Haggith and Joanna Newman (London: Wallflower Press, 2005), 194.

${ }^{2}$ Yosefa Loshitzky, "Introduction," in Spielberg's Holocaust: Critical Perspectives on Schindler's List, ed. Yosefa Loshitzky (Bloomington: Indiana University Press, 1997), 3.
} 
The Holocaust claimed the lives of approximately six million European Jews. As such, there is a heavy burden on any filmmaker to be respectful with their representations. ${ }^{3}$ There is great debate over how, and even if, such a disturbing event should be represented through film. One of the most prominent concerns over the making of Holocaust films is that the dead might be dishonoured or disrespected by their representations. In response to this concern, author Aaron Kerner writes about a set of three rules that have implicitly guided much of the critical body of Holocaust films to date. The first of these rules is that the Holocaust must be treated as an entirely unique event and a special case in history. The second rule is that representations of the Holocaust should be as true to the facts and events of the Holocaust as possible, and should avoid manipulations. The final rule guiding Holocaust films is that the Holocaust should be treated as a solemn and sacred event. ${ }^{4}$ These rules have acted as guiding principles for Holocaust films that seek to be respectful and non-offensive in their representations. The rules are not explicit and can be broken, but do shape what many viewers expect to see in varying genres of Holocaust films, including those which will be explored by this essay. The following section of this essay will compare and contrast the unique portrayals of the Holocaust offered by Schindler's List, In Darkness, and The Last Days.

Schindler's List is a biopic film centred on the life of Oskar Schindler, a German businessman who was able to save the lives of 1,100 Jews during the Holocaust by employing them in his factory. The film is based on the book Schindler's Ark, which was written in large part due to the persistence of one of the Jews who worked in Schindler's factory, Leopold Pfefferberg. Thomas Keneally, author of Schindler's Ark, credits Pfefferberg in his book for encouraging him to write about Oskar Schindler and to share his story with the world. ${ }^{5}$ Schindler's Ark is based on interview accounts of more than 50 of the Jews that Schindler worked to save. The Jews interviewed for the book largely agreed that Schindler's motivations were originally to exploit Jewish labour for his own benefit, but this inexplicably changed somewhere along the way and Schindler ended up risking his life and giving up all of his wealth to protect his workers. The screen rights to Schindler's Ark eventually came into the possession of director Steven Spielberg, who directed the film Schindler's List. ${ }^{6}$ The real Oskar Schindler and his wife Emilie were both recognized as Righteous Among Nations in 1993. ${ }^{7}$

In Darkness is a Polish-made drama film based on the true story of a small group of Polish-Jews who were able to survive the Holocaust by hiding in the sewers of Lwów for 13 months with the help of Polish sewage inspector Leopold Socha. At the beginning of the film, Socha charges the Jews for hiding in the sewers, but later on when the Jews run out of money, he allows them to stay there for free and continues to bring them supplies. ${ }^{8}$

\footnotetext{
${ }^{3}$ Doris Bergen, War and Genocide: A Concise History of the Holocaust, $2^{\text {nd }}$ ed. (Plymouth: Rowman and Littlefiend Publishers, Inc, 2009), vii.

${ }^{4}$ Aaron Kerner, Film and the Holocaust: New Perspectives on Dramas, Documentaries and Experimental Films, (New York: Bloomsbury, 2011), 3.

${ }^{5}$ Thomas Keneally, Schindler's List. (New York: Simon \& Schuster, 2000), 9-10.

${ }^{6}$ Frank Manchel, "A reel witness: Steven Spielberg's representation of the Holocaust in Schindler's List," Journal of Modern History 67, no. 1 (1995): 84-85. America: History and Life with Full Text. 7 "Oskar and Emilie Schindler", The Righteous Among the Nations, Yad Vashem The Holocaust Martyrs' and Heroes' Remembrance Authority http://www.yadvashem.org/yv/en/righteous/stories/schindler.asp. ${ }^{8}$ In Darkness, directed by Agnieszka Holland, (New York, NY: Sony Pictures Classics, 2012), DVD.
} 
Originally 21 Jews hid in the sewers with the help of Socha, but after 13 months under the harsh conditions of the sewage canals only 10 of them survived. The real Leopold Socha and his wife were recognized as Righteous Among Nations in $1978 .{ }^{9}$

The Last Days is a historical documentary, which focuses on the true stories of survival of five Hungarian-Jews who lived through the concentration camps. In the film the survivors recount their experiences during the eradication of the Jewish population in Hungary. Archival footage and photos are featured to depict the stories that the survivors tell. The film follows the survivors as they revisit their old homes, as well as the ghettos and concentration camps in which they were incarcerated. Some of the survivors make an effort to look up family records and find out what became of their loved ones during the Holocaust. This film brings in a variety of perspectives including those of American soldiers who liberated Dachau and even a former Nazi doctor who worked at Auschwitz and was directly involved in human experimentation. ${ }^{10}$

As the Holocaust is a very grim event to depict through film, it is interesting to examine a filmmaker's motivations for creating a Holocaust film. Notably, both Steven Spielberg, the director of Schindler's List and producer of The Last Days, and Angieszka Holland, the director of In Darkness, have close family ties to Holocaust victims. Both cite these personal ties as influencing them to create films that many other directors may have shied away from. As Spielberg discusses in an interview about Schindler's List, he grew up in an Orthodox Jewish household and his grandparents lost relatives in Eastern Europe during the Holocaust. Spielberg explains in the interview that he wanted to pass something along to his children about the Holocaust, and chose to do this through Schindler's List. ${ }^{11}$ In an interview with Holland, she explains that her own father was a Holocaust survivor, and that his whole family was killed during the massacre. Holland previously directed two other Holocaust films, Angry Harvest and Europa Europa, and in her interview describes originally turning down the opportunity to direct In Darkness, as she did not want to relive the difficult experience of directing a film of this nature. ${ }^{12}$ Spielberg similarly describes filming Schindler's List as a difficult experience for all of the cast and crew involved, but was so inspired by making the film that he founded the Shoah Foundation with the goal of increasing awareness of the Holocaust through the collection of recorded survivor testimonies. To date, the foundation has compiled more than 50,000 survivor testimonies in 34 different languages. ${ }^{13}$ The survivor testimonies collected by the Shoah Foundation largely influenced the creation of The Last Days, which chose five of the Hungarian survivors interviewed to be the focus of the film. ${ }^{14}$ The personal links that both Spielberg and Holland hold to Holocaust victims appear to have inspired not only their decision to

\footnotetext{
9 "Leopold and Magdalena Socha", The Righteous Among the Nations, Yad Vashem The Holocaust Martyrs' and Heroes' Remembrance Authority http://www.yadvashem.org/yv/en/righteous/stories/socha.asp.

${ }^{10}$ The Last Days, directed by James Moll, (Hollywood, CA: Universal Studios, 1998), DVD.

${ }^{11}$ Steven Spielberg, "Face to face Steven Spielberg part 2." Originally aired January 31, 1994 by BBC. YouTube video, 5:59. Posted November 28, 2009, https://www.youtube.com/watch? v=yvLP-4KPNPs.

${ }^{12}$ Agnieszka Holland, "Agnieszka Holland on In Darkness" Originally aired February 3, 2012 by The Jewish Channel. YouTube video, 5:45. Posted February 10, 2012, https://www.youtube. com/watch?v=0u4kPvgrpiY.

13 "About the Institute," USC Shoah Foundation: The Institute for Visual History and Education, para.1, n.d., http://sfi.usc.edu/about/institute.

14 The Last Days, DVD.
} 
make films about the Holocaust, but also their desire to portray it as tactfully and accurately as possible.

Schindler's List, In Darkness and The Last Days, though all focused on the Holocaust, fit into different genre and subgenre categories. With the wide release of many Holocaust films, the Holocaust film has become something of its own subgenre, a variation of the traditional war film subgenre. There is some concern over the Holocaust film becoming its own subgenre, as it is very difficult to construct parameters for the representation of such a horrific event. ${ }^{15}$ Schindler's List is a biopic film set during the Holocaust. A biopic film presents the case that individual people are central to the historical process and are worth studying based on their individual lives or actions. ${ }^{16}$ In the case of Schindler's List, the individual person who is studied is Oskar Schindler. Schindler's actions saved the lives of many Jews during the Holocaust, making his life an interesting focus for a film. One of the subgenres that can be seen in Schindler's List is film noir. A key trait of film noir is the use of deep shadows and high contrast lighting. Through the use of this film noir style, Oskar Schindler's face is often wreathed in shadow throughout the first section of the film. ${ }^{17}$ In Darkness is a historical drama. Historical dramas portray real historical events through the use of many tools such as compression of time, development of characters and creation of dialogue. ${ }^{18}$ This film can also be classified as a biopic film, as the film's main character Leopold Socha was a real person who truly did help ten Jews to survive the Holocaust by hiding in the sewers. This film's dominant genre is a historical drama rather than a biopic because Socha is not the dominant focus of the film. Instead of focusing entirely on Socha, the film's focus is split quite evenly between Socha and the Jews. The Last Days is a historical hybrid documentary. A documentary provides a direct reflection of the world and attempts to show what was once there had no camera been present. ${ }^{19}$ The Last Days is a hybrid documentary because it combines survivor testimonies, archival footage and current footage. This documentary creates an interactive model of history, which relies on empirical facts of the past, but also encourages the audience to interpret what they see for themselves. ${ }^{20}$ The Last Days successfully creates an interactive model of history by presenting symbolic shots for viewers to interpret such as a flower growing outside of a former concentration camp. The Last Days is also interactive because it offers different perspectives on the Holocaust for viewers to consider such as the former Nazi doctor featured in the film who contrasts the perspectives of the Jewish survivors. The different genres of the films create three unique representations of the Holocaust.

Metaphors and symbolism are present in both similar and disparate ways in these three films. A key form of symbolism present in all of the films is the use of light and colour. Light and colour are particularly important symbols in Schindler's List, which was purposely filmed in almost entirely black and white. Schindler's List opens with colour,

\footnotetext{
${ }^{15}$ Barry Langford, Film Genre: Hollywood and Beyond, (Edinburgh: Edinburgh University Press Ltd., 2005), 264-265.

${ }^{16}$ Robert Rosenstone, History on Film/ Film on History, $1^{\text {st }}$ ed. (Harlow: Pearson, 2006), 90.

${ }^{17}$ Langford, Film Genre, 264.

${ }^{18}$ Rosenstone, History on Film, 39.

19 Ibid. 70.

${ }^{20}$ Judith Lancioni, "The Civil War: A Battleground of Meaning", Film and History: An Interdisciplinary Journal of Film and Television Studies 38, 1. (2008): 25, http://library.mtroyal.ca:2118/journals/film_and_history/ v038/38.1.lancioni.html.
} 
mostly focusing on a burning candle while Jewish prayer is being recited in the background. As the candle melts down, the colour and light slowly begin to fade from the scene. When the candle is finally extinguished, the colour disappears and does not come back until the very end of the film when the Holocaust is over. The fact that the film was done in black and white seems to be metaphoric for the lack of light, or lack of hope during the Holocaust. As director Steven Spielberg describes in an interview, the Holocaust seems more real and alive to him in black and white, as he only knows it through black and white photos and archival footage. ${ }^{21}$ During the body of Schindler's List, the only instance where colour is used is when Schindler is overlooking the Krakow ghetto during its evacuation. This scene is entirely black and white with the exception of a small girl in a red coat who catches Schindler's attention. The girl is wearing a very bright and noticeable red coat, yet walks through the streets unnoticed by the Nazi troops. ${ }^{22}$ As Spielberg discusses in another interview, the red-coated girl in this scene is a metaphor for the Holocaust itself, which was quite obviously occurring and known about by foreign leaders, yet went ignored. ${ }^{23}$

The film In Darkness is filmed in colour, but despite this, it is very dark and dimly lit. The film is largely set in the sewers of Lwów where the only source of light is a lantern. While the plot is taking place above ground, the sky is constantly dim and grey. Similar to Schindler's List, the use of darkness and dimmed colours in In Darkness seems to represent the lack of hope and happiness during the Holocaust. At the end of the war in In Darkness, Socha tells the Jews that they are free and can come out of the sewers. When the Jews eventually come back up to street level to claim their freedom the film depicts a bright day with a blue sky, symbolic of hope for the future. Director of In Darkness, Agnieszka Holland describes the darkness in the film to be a metaphor for the ultimate Jewish destination in the Holocaust, death and eradication. Furthermore, Holland explains Socha always carrying a lantern is a metaphor depicting that the light is coming out of him, as he is the only one who can save this group of Jews. ${ }^{24}$

The Last Days, like In Darkness, is also filmed in colour, but uses a large number of black and white photos and footage to depict the stories that the Holocaust survivors tell. Late in the film, following the survivors' discussion of their liberation, current footage overlooking a former concentration camp is shown. The camp is bright green with new plant growth, and there is a colourful flower blooming. This bright shot, in contrast to the dark and dim footage from the Holocaust seems to be symbolic for new life and new beginnings after the Holocaust. Colour and light seem to be used similarly throughout each film to depict the hopeless scenario of the Holocaust and the joy of its ending, however Schindler's List takes this symbolism further than the other films by presenting nearly the entire film in black and white.

Schindler's List and In Darkness both symbolically portray that Jews are of a much lower status than Germans and common people. In the film In Darkness, Jews are metaphorically turned into rats living in the sewers. Rats can be heard squeaking

\footnotetext{
${ }^{21}$ Spielberg, "Face to face Steven Spielberg part 2," 5:59.

22 Schindler's List, directed by Steven Spielberg, (Hollywood, CA: Universal Studios, 1993), DVD.

${ }^{23}$ Steven Spielberg, "Steven Spielberg on Schindler's List," YouTube video, 9:23. Posted July 19, 2008 https:// www.youtube.com/watch?v=fAM5q837enk.

${ }^{24}$ Agnieszka Holland, "Agnieszka Holland on her Oscar-nominated film, 'In Darkness'” interviewed by Naomi Pfefferman from Jewish Journal. YouTube video, 5:44. Posted February 1, 2012 https://www.youtube.com/ watch?v=i1P_Fl4F8HU.
} 
throughout the film and are often complained about. Early in the film, Socha is frustrated with the Jews living in his sewers and when he hears a rat squeaking, he yells "God damn rats, God damn vermin". ${ }^{25}$ Though there is a literal rat present, it is clear that Socha is referring to the Jews with this line. By the end of the film, once the Jews are saved, Socha shows just how much he has become attached to the Jews and that he now thinks of them as more than vermin by emotionally exclaiming, "these are my Jews, these are my work". ${ }^{26}$ Schindler's List depicts a liberal amount of symbolism relating to the status of Germans in relation to Jews. Early in the film, Schindler is up in his office looking down at his workers from his window. While the Krakow ghetto is being cleared, Schindler watches from a hilltop while on horseback, looking down on the situation below. Much later in the film, there is a symbolic coming of equality after Schindler purchases the Jewish workers and moves them to his new factory. While in his new factory, Schindler walks with Itzhak across the factory floor, now on level with his workers instead of looking down at them through a window. At the very end of the film, an even larger change in dynamic can be seen when Schindler says goodbye to his workers. Here Schindler becomes emotional, wishing that he had saved more people and sinks down to his knees in grief. In this scene Schindler seems to lose all of his previous sense of status and symbolically shows that he values the lives of the Jews even more than he values his status and material wealth. Both In Darkness and Schindler's List symbolically show inequality between Jews and others. In Darkness portrays the inequality between Jews and common people, and Schindler's List portrays the inequality between Germans and Jews. Both films show a reconciliation of equality at the end of the war.

All three of the Holocaust films being analyzed put an effort into making the audience feel as if they personally experienced the events that they depict. Schindler's List and In Darkness both employ camera movement in order to achieve this, while The Last Days relies on authentic footage and photographs. In Schindler's List, there are a few scenes in which the audience is made to feel as if they are part of the chaos through camera movement. One of these scenes is during the clearing of the Krakow ghetto. In this scene, people are frantically running around on the streets, attempting to escape and hide from the Nazi soldiers. The camera is at eye level with everyone in the ghetto and is moving and shaking as if to show what a person who was there might have seen and felt. A similar tactic is used when the female Jews are accidentally taken to Auschwitz and crammed into the shower room. In this scene the camera is again shaky and at eye level as it follows the women into the shower room. Here, the audience is able to share the experience of fear and helplessness with the women first hand. The film In Darkness also uses camera movement to show the audience what the characters in the film are seeing. An example of this is when a young girl hiding in the sewer is brought up to street level to get a glimpse of light. After being down in the dark sewers for so long, the girl's eyes do not adjust to the light right away and the camera shows an overly bright and blurred image of the streets to mimic what the girl is seeing and that the light is hurting her eyes. The Last Days uses a different method of portraying the perspective of the Holocaust survivors, and instead shows archival footage and photographs to show what the Holocaust survivors are discussing. An example of this is when survivor Renée Firestone is talking about the bathing suit she loved

\footnotetext{
${ }^{25}$ In Darkness, DVD.

${ }^{26}$ Ibid.
} 
so much that her father gave her. While she is reminiscing, the film shows an old picture of her wearing her beloved bathing suit. Schindler's List and In Darkness both employ camera movement to help the audience see the characters' perspectives, The Last Days also offers a very real insight into the survivors' minds and perspectives, but through the use of old footage and photos instead of camera movement.

A good historical film can be an excellent tool that offers audiences a look into the past through a focused and narrative slice of history. ${ }^{27}$ With film being accepted as a medium for telling history, it is important for audiences to be aware of some of the tools that filmmakers might use to develop an increased sense of verisimilitude in their proximate realities. As the documentary is the genre of film that is expected to provide the most direct representation of history, it is interesting to analyze some of the tools that The Last Days employs to enhance its perceived legitimacy. The Last Days brings authenticity to its audience through the use of archival photos and footage, which are interpreted by the accounts of Holocaust survivors. For a viewer of The Last Days, or any similar style of documentary film, it is important to be mindful of the fact that although the footage used may be authentic, a filmmaker can use or omit footage selectively to communicate a certain message. ${ }^{28}$ This is not to argue that The Last Days should not be accepted as a strong historical document, rather to note that even a trusted documentary film should be viewed with a critical eye. To increase its verisimilitude, the characters in the film In Darkness all speak their true languages, including; Polish, German, Yiddish and Ukrainian. This directorial decision seems to create a more authentic recreation, as the characters all communicate in the languages that they truly would have historically, rather than simply in English. Schindler's List employs a number of tools to increase the authenticity of its depiction. The decision to film in black and white for example, amongst the other purposes examined, appears to be as one author writes, "...suggestive of genuine documentary footage" ${ }^{29}$ Other tools employed by Schindler's List include the handheld cinematography, and highly accurate work recreating areas such as the Krakow ghetto and the camps that were used as settings for the film. All three of the films examined make use of unique tactics to increase their believability. While the documentary format of The Last Days alone is enough to make the film appear trustworthy to audiences, In Darkness and Schindler's List both utilize additional tactics to increase their perceived authenticity.

As Kerner writes in his book on film and the Holocaust, something common to many Holocaust films is that the Jewish victims are feminized, while the Nazi perpetrators are represented to be horrifically powerful and merciless. ${ }^{30}$ This may seem unsurprising as the Holocaust truly did see Jews largely powerless and at the mercy of Nazi soldiers, however filmmakers do have the option to choose the level to which they represent these stereotypes, and are free to showcase characters that break them. For all three of the films

\footnotetext{
${ }^{27}$ Ian Wall, "The Holocaust, Film and Education," in Holocaust and the Moving Image: representations in film and television since 1933, eds. Toby Haggith and Joanna Newman (London: Wallflower Press, 2005), 204-205.

${ }^{28}$ Elizabeth Cowie, "Seeing and Hearing for Ourselves: the spectacle of reality in the Holocaust Documentary," in Holocaust and the Moving Image: representations in film and television since 1933, eds. Toby Haggith and Joanna Newman (London, Wallflower Press, 2005), 183.

${ }^{29}$ Sara R. Horowitz, "But Is It Good For the Jews? Spielberg's Schindler and the Aesthetics of Atrocity" in Spielberg's Holocaust: Critical Perspectives on Schindler's List, ed. Yosefa Loshitzky, (Bloomington: Indiana University Press, 1997), 122.

${ }^{30}$ Kerner, Film and the Holocaust, 5.
} 
being analyzed, the portrayal of Nazis as cruel and formidable can be explored. In Schindler's List, Amon Goeth, the commander of the Krakow-Plaszow camp is the main Nazi of focus and becomes symbolic of all Nazis in the film. Goeth is an extremely cruel and emotionally detached character. A strong example of his cruelty in the film is the scene in which he wakes up in the morning and precedes to his balcony with a rifle. From his balcony he aims his rifle down at the concentration camp and begins to shoot and kill Jews as if for sport. He kills one Jew who simply bends down to tie his shoe and then kills another who is just sitting down. After killing these people, Goeth's cruelty is further developed when he casually stretches and returns to bed with his female companion. Goeth shows no remorse for his actions. The film In Darkness shows a similar cruelty and detachment from Nazi soldiers. A shocking scene in this film is when Mundek arrives at the concentration camp to look for Klara's sister. In this scene, Mundek is singled out by a Nazi official for not having a hat. The Nazi tells Mundek that he has no business being there without a hat, and aims a gun at his head to shoot him. Another Nazi intervenes, saying that Mundek is too healthy to kill, and then precedes to shoot the more frail looking man beside Mundek and tells him to retrieve the man's hat for himself. The Last Days depicts similar cruelty through the stories of the survivors. One of the survivors describes that if someone tried to run into the electric fence and kill themselves in the camp, the Nazis would stop them from killing themselves and would then punish them by killing others who had done nothing. Schindler's List and In Darkness both use similar tactics to create the perception that Nazis were cruel and brutal to Jews, The Last Days creates the same perception but does so differently through the use of survivor testimony.

The films' portrayals of Jews as both feminized and victimized can also be examined. Schindler's List depicts many scenes where Jews are depicted as feminized victims. One of these scenes is the uncomfortable sexual near-encounter between the Aryan Amon Goeth and Jewish Helen Hirsch. In this scene, Goeth takes notice of Hirsch's feminine body and physical nearness and follows her into her living quarters. Once inside, it appears that Goeth may force himself on Hirsch sexually, but after a long and uncomfortable internal struggle, Goeth resolves to physically beat her instead. In this scene Hirsch represents the stereotype of Jews in regards to both feminization and victimization, as she is weak and defenseless to whatever action Goeth decides to take. In the film In Darkness, the Jewish characters are similarly depicted as feminized victims. In the film the Jews are weak, afraid and reliant on Socha for their continued lives. Though In Darkness does conform to the stereotype of the feminized Jewish victim, it also breaks the stereotype by spotlighting a very strong Jewish character, Mundek. A powerful scene in In Darkness shows Mundek going out scavenging for items in the abandoned ghetto and encountering a German soldier. Upon this encounter Mundek manages to disarm and kill the soldier with a hammer. In Darkness accomplishes two things with this scene, not only does it break the feminized Jew stereotype, but it also breaks the all-powerful German stereotype by showing weakness in the soldier. In The Last Days, the Jewish subjects of the documentary are feminized, but also depicted as very strong people. The stories that the survivors tell about their experience during the Holocaust initially paint them as powerless victims at the mercy of the Nazis. While exposing the horrors the survivors lived through, the film also makes a point of showing how far the survivors have come since the Holocaust. The Last Days shows that its Jewish subjects have not only survived, but are thriving in their adult lives and are heroically working to educate others about their experiences. As common amongst 
Holocaust films, Jews are portrayed as weak and feminized in each of the three films analyzed by this paper. Interestingly, In Darkness shows a Jew breaking this stereotype by fighting back against a German, and The Last Days depicts a similar strength in the Jews by showing how a small group of Jews have thrived since the Holocaust.

The Holocaust is an appalling event in modern history. With so many films about it having been released, there is concern that the truly shocking things depicted may become expected conventions in Holocaust films. As In Darkness director Agnieszka Holland discusses in an interview, she believes that many Holocaust films stay too close to the conventions expected of them and do not depict a harsh enough vision of the Holocaust. Holland argues that audiences are largely becoming desensitized to some expected images in Holocaust films, such as skeletons and barbed wire fences, and are beginning to look at them without emotion. ${ }^{31}$ If Holland is correct with this argument, Holocaust filmmakers now face the challenge of finding new and unexpected ways to communicate the horrors of the Holocaust to audiences, while at the same time preserving the dignity of the victims. In Schindler's List, the shower scene previously analyzed is a strong representation of a scene that pushed the boundaries of what was expected in a Holocaust film and was shocking to audiences at the time of the film's release. Interestingly, Holland, who endorses pushing the boundaries to reach audiences, notes that she has a problem with Spielberg's choice to film this scene, stating in an interview, "...there are some places I will not go with the fictional camera". ${ }^{32}$ In her own film In Darkness, Holland attempts to shock and disturb audiences right from the opening scene, which shows a group of naked women running through the woods crying before being shot down by Nazi soldiers. Without any build up or warning, Holland immediately attempts to upset her audience and introduce them to the horrors of the Holocaust. Due to the graphic nature of the Holocaust, The Last Days effectively shocks its audience and communicates the horror of the Holocaust simply through the use of disturbing archival images and footage of things such as piles of bodies in mass graves. All three of the films find effective ways to communicate the atrocities of the Holocaust to their audiences. As more and more Holocaust films are released, the number of new and shocking things that can be offered by films will continue to diminish, however the horror of the real event will remain the same.

Schindler's List, In Darkness and The Last Days all provide unique interpretations of the Holocaust brought to audiences from filmmakers with personal ties to victims. Each film is from a different genre and as such, contains conventions unique to its genre. Symbolism is used throughout each of the three films. An important symbol in all three films is light and colour, and an important symbol in Schindler's List and In Darkness is the implied status of the Jews below Germans and common people. Camera movement is used in In Darkness and Schindler's List to make the audience feel as if they experienced some of the events first hand. In The Last Days a similar experience is created through the use of old footage and photos. Different tools are employed by each of the films to develop an authentic feeling proximate reality, including archival footage used by The Last Days, real languages used by In Darkness, and the black and white colour scheme used by Schindler's List. All three films create the perception that the Nazis were cruel and merciless, Schindler's List and In Darkness do this similarly by portraying cruel Nazi characters, while

\footnotetext{
${ }^{31}$ Holland, "on her Oscar-nominated film 'In Darkness,'” 5:44.

32 Ibid.
} 
The Last Days relies on survivor testimonies. Similarly, all three films create a perception of Jews as feminine and weak, however In Darkness and The Last Days both showcase Jews that overcome this perceived weakness. To depict the harshness of the Holocaust, each of these films effectively employs disturbing and graphic scenes and shots to shock their audiences. Through the comparison of Schindler's List, In Darkness and The Last Days, three unique representations of the Holocaust through film can be seen, and a number of differences in film language tactics used by disparate genres of Holocaust films can be identified. 
Cross, "Genres of Holocaust Films," 91

\section{BIBLIOGRAPHY}

\section{SECONDARY SOURCES}

\section{Books and Book Chapters}

Bergen, Doris, War and Genocide: A Concise History of the Holocaust. $2^{\text {nd }}$ ed. Plymouth, United Kingdom: Rowman and Littlefield Publishers, Inc. 2009.

Cowie, Elizabeth, "Seeing and Hearing for Ourselves: the spectacle of reality in the Holocaust Documentary," in Holocaust and the Moving Image: representations in film and television since 1933, edited by Toby Haggith and Joanna Newman, 182-192, London, Wallflower Press, 2005.

Gold, Trudy, "An overview of Hollywood cinema's treatment of the Holocaust," in Holocaust and the Moving Image: Representations in Film and Television since 1933, edited by Toby Haggith and Joanna Newman, 193-197. London: Wallflower Press, 2005.

Horowitz, Sara R. "But Is It Good For the Jews? Spielberg's Schindler and the Aesthetics of Atrocity" in Spielberg's Holocaust: Critical Perspectives on Schindler's List, edited by Yosefa Loshitzky, 119-139, Bloomington: Indiana University Press, 1997.

Keneally, Thomas, Schindler's List. New York: Simon \& Schuster, 2000.

Kerner, Aaron, Film and the Holocaust: New Perspectives on Dramas, Documentaries and Experimental Films, New York: Bloomsbury, 2011.

Langford, Barry, Film Genre: Hollywood and Beyond. Edinburgh, United Kingdom: Edinburgh University Press Ltd., 2005.

Loshitzky, Yosefa, "Introduction," in Spielberg's Holocaust: Critical Perspectives on Schindler's List, edited by Yosefa Loshitzky, 1-17. Bloomington: Indiana University Press, 1997.

Rosenstone, Robert, History on Film/ Film on History. $1^{\text {st }}$ ed. Harlow, United Kingdom: Pearson, 2006.

Wall, Ian, "The Holocaust, Film and Education," in Holocaust and the Moving Image: representations in film and television since 1933, edited by Toby Haggith and Joanna Newman, 203-210, London: Wallflower Press, 2005.

\section{Reference Works}

Lancioni, Judith "The Civil War: A Battleground of Meaning", Film and History: An Interdisciplinary Journal of Film and Television Studies 38, 1. (2008): 21-29. http:// library.mtroyal.ca:2118/journals/film_and_history/v038/38.1.lancioni.html 
Manchel, Frank, "A reel witness: Steven Spielberg's representation of the Holocaust in Schindler's List," Journal of Modern History 67, no. 1 (1995): 83-100. America: History and Life with Full Text.

\section{Webpages and Websites}

"About the Institute", USC Shoah Foundation: The Institute for Visual History and Education. Accessed July 12, 2014 http://sfi.usc.edu/about.

"Leopold and Magdalena Socha", The Righteous Among the Nations, Yad Vashem The Holocaust Martyrs' and Heroes' Remembrance Authority. Accessed March 15, 2014. http://www.yadvashem.org/yv/en/righteous/stories/socha.asp.

"Oskar and Emilie Schindler", The Righteous Among the Nations, Yad Vashem The Holocaust Martyrs' and Heroes' Remembrance Authority. Accessed March 15, 2014 http:// www.yadvashem. org/yv/en/righteous/stories/schindler.asp.

\section{Video}

Holland, Agnieszka, "Agnieszka Holland on her Oscar-nominated film, 'In Darkness'” interviewed by Naomi Pfefferman from Jewish Journal. YouTube video, 5:44. Posted February 1, 2012. https://www.youtube.com/watch?v=i1P_Fl4F8HU.

Holland, Agnieszka, "Agnieszka Holland on In Darkness" Originally aired February 3, 2012 by The Jewish Channel. YouTube video, 5:45. Posted February 10, 2012. https:// www.youtube. com/watch?v=0u4kPvgrpiY.

In Darkness, directed by Agnieszka Holland. New York, NY: Sony Pictures Classics, 2012.

Schindler's List, directed by Steven Spielberg. Hollywood, CA: Universal Studios, 1993.

Spielberg, Steven, "Face to face Steven Spielberg part 2." Originally aired January 31, 1994 by BBC. YouTube video, 5:59. Posted November 28, 2009. https:// www.youtube.com/watch?v=yvLP-4KPNPs.

Spielberg, Steven, “Steven Spielberg on Schindler's List," YouTube video, 9:23. Posted July 19, 2008. https://www.youtube.com/watch?v=fAM5q837enk.

The Last Days, directed by James Moll. Hollywood, CA: Universal Studios, 1998. 